\title{
Rheumatoid Factor Antibody IgG Measurement
}

National Cancer Institute

\section{Source}

National Cancer Institute. Rheumatoid Factor Antibody Ig G Measurement. NCI

Thesaurus. Code C120653.

The determination of the rheumatoid factor antibody IgG present in a sample. 